Retraction

\title{
Financing Higher Education in Ethiopia: Analysis of Cost-Sharing Policy and its Implementation
}

Sewale Abate Ayalew

Higher Education Policy (2013) 26, 429. doi:10.1057/hep.2013.15;

published online 11 June 2013

Retraction to: Higher Education Policy (2013) 26, 109-126. doi: 10.1057/hep.2012.21; published online 21 August 2012

The editor and publisher of Higher Education Policy are retracting the article 'Financing Higher Education in Ethiopia: Analysis of Cost-Sharing Policy and its Implementation' by Sewale Abate Ayalew (2013) (http://www.palgrave-journals. com/hep/journal/v26/n1/full/hep201221a.html), published in Volume 26 Issue 1 of the journal, following an investigation into possible ethical misconduct. It has been concluded that portions of text in the article are either unoriginal or incorrectly cited, and therefore the decision has been taken to remove this article from the scholarly field. It should no longer be cited from the print or online version of Higher Education Policy. 